\title{
O Memorial da Resistência em fotos de visitantes no Instagram: modos de ver, sentir e pensar o passado, o presente e o futuro
}

\begin{abstract}
Resumo
Este artigo visa investigar as múltiplas temporalidades que embasam as imagens feitas e publicadas nas redes sociais por visitantes do Memorial da Resistência de São Paulo. Por meio da análise de algumas dessas fotografias, coletadas no Instagram, busca-se evidenciar aquilo que elas iluminam sobre visões, sentimentos e pensamentos acerca do passado, do presente e do futuro - como permitidos por esse museu e lugar de memória e como traduzida visualmente pelos indivíduos que experienciaram o espaço.
\end{abstract}

Palavras-chave: Fotografia. Redes Sociais. Museus. Memorial da Resistência de São Paulo.

\author{
Ana Carolina Lima Santos \\ Doutora em Comunicação Social pela \\ Universidade Federal de Minas Gerais \\ (UFMG). Professora da Universidade \\ Federal de Ouro Preto (UFOP). \\ Mariana, MG - BRASIL \\ outracarol@gmail.com \\ orcid.org/0000-0001-6973-6401
}

\section{Para citar este artigo:}

SANTOS, Ana Carolina Lima. O Memorial da Resistência em fotos de visitantes no Instagram: modos de ver, sentir e pensar o passado, o presente e o futuro. Tempo e Argumento, Florianópolis, v. 11, n. 27, p. 101 -128, maio/ago. 2019.

DOI: 10.5965/2175180311272019101

http://dx.doi.org/10.5965/2175180311272019101 
The Memorial of Resistance in Instagram pictures of visitors: ways of seeing, feeling and thinking about the past, the present and the future

\begin{abstract}
This article aims to investigate the multiple temporalities that appear in images made and published in social networks by visitors of Memorial of Resistance of São Paulo. Through the analysis of some of these photographs, collected in Instagram, the paper tries to highlight visions, feelings and thoughts about the past, the present and the future that these photos illuminate - as allowed by this museum and site of memory and as visually translated by individuals who have experienced the place.
\end{abstract}

Keywords: Photography. Social Networks. Museums. Memorial of Resistance of São Paulo.

\section{El Memorial de la Resistencia en fotos de visitantes en el Instagram: modos de ver, sentir y pensar el pasado, el presente y el futuro}

\begin{abstract}
Resumen
En este artículo se pretende investigar las múltiples temporalidades de las imágenes tomadas y publicadas en las redes sociales por visitantes del Memorial de la Resistencia de São Paulo. A través del análisis de algunas de esas fotografías, recogidas en Instagram, se pone en evidencia visiones, sentimientos $y$ pensamientos sobre el pasado, presente y futuro que las imágenes iluminan - a partir de lo que ese museo y lugar de la memoria proporciona y de la forma cómo los individuos han traducido visualmente sus experiencias en el sitio.
\end{abstract}

Palabras clave: Fotografía. Redes Sociales. Museos. Memorial de la Resistencia de São Paulo.

\section{Introdução}

O Memorial da Resistência de São Paulo é o principal museu e lugar de memória dedicado à preservação e à comunicação das histórias da ditadura civil-militar que assolou o Brasil entre 1964 e 1985. Inaugurado em janeiro de 2009, na antiga sede do Departamento Estadual de Ordem Política e Social do Estado de São Paulo (DEOPS/SP), ele visa "estimular o debate sobre os problemas referentes aos períodos de governos ditatoriais [...], a partir da perspectiva da 'resistência' em suas distintas expressões" (BRUNO; ARRUDA; FIGOLS, 2010, p. 6). Para isso, a instituição busca (re)construir interpretações acerca do passado tanto quanto interpelar um senso de futuro, a fim de transfigurar entendimentos sobre certos temas, para então extrair lições atuais. O texto de abertura do Memorial assume essa dupla função ao dizer que, nele, 
[...] a partir das memórias daqueles que resistiram [à violência do Estado durante a ditadura], foi possível desvelar uma nova vocação para este espaço e prepará-lo para que as novas gerações encontrem, aqui, não só as informações sobre as atrocidades da repressão, mas, sobretudo, as inspirações para a valorização da solidariedade, dos princípios democráticos e do respeito à diferença. (ARAUJO; BRUNO, 2009, p. 75)

O modo como passado e futuro se entrelaçam no projeto museológico parece igualmente guiar a forma como os visitantes reagem ao Memorial. Em uma avaliação do livro de visitas da instituição, realizada nos primeiros seis meses de funcionamento, verificou-se que boa parte das impressões ali registradas se relaciona "à percepção da importância de espaços como esse para a preservação da memória e para que regimes ditatoriais não voltem a acontecer" (ARAUJO; BRUNO; NEVES; MENEZES, 2009, p. 168). Partindo dessa constatação, o presente artigo ${ }^{1}$ intenciona analisar a maneira como as diferentes temporalidades também se imbricam na produção fotográfica que os indivíduos realizam durante as visitas ao Memorial da Resistência, tomando como base as imagens postada no Instagram². Supõe-se, de partida, que as fotografias feitas no museu e publicadas na rede social estão marcadas por essa dupla perspectiva, que abaliza o passado e aponta para o futuro.

As fotografias aqui trabalhadas foram coletadas através de buscas por hashtags, etiquetas comumente utilizadas no Instagram para categorizar as postagens - e que, dispostas como hiperlinks, apresentam conteúdos de diferentes usuários em uma listagem, agrupados em torno de assuntos comuns. Os termos procurados foram: \#memorialdaresistencia (que retornou 1.816 publicações), \#memorialdaresistência (500), \#memorialdaresistenciasp (280) e \#memorialdaresistenciadesaopaulo (60). Uma vez que a intenção era explorar as imagens dos visitantes, foram excluídas as fotografias postadas com fins institucionais ou de divulgação, a exemplo de publicações do próprio

\footnotetext{
${ }^{1}$ Agradeço a Mauricio Lissovsky pelas sugestões feitas ao primeiro rascunho do artigo, acolhidas nesta versão.

${ }^{2}$ De acordo com pesquisa realizada pela empresa comScore, o Instagram é a terceira rede social na qual os brasileiros gastam mais tempo, aparecendo atrás do Facebook e do Messenger. Ao analisar o engajamento por usuário e ao focar nos chamados millennials (pessoas entre 18 e 34 anos), o Instagram também ocupa a terceira posição, com Facebook e Snapchat antes dele. Entretanto, nessas outras redes, a fotografia divide espaço com conteúdos de natureza diversa, como textos, gifs e vídeos. O Instagram, embora permita a postagem de pequenos vídeos e as imagens possam vir acompanhadas de textoslegendas, tem na fotografia sua maior força. Informações disponíveis em: <https://pt.slideshare.net/lefil/brasil-digital-do-futuro-comscore-2016>. Acesso em 20 abr. 2017.
} 
perfil do Memorial $^{3}$ e de outras entidades, como órgãos públicos, organizações não governamentais, veículos de comunicação e afins. A partir de um pré-exame, algumas imagens foram selecionadas para discussão, escolhidas por apresentarem elementos observados como recorrentes.

Para esmiuçar essas fotografias, foram úteis as pistas fornecidas por Hilmar (2016) na apreciação de imagens feitas no antigo campo de extermínio nazista de Auschwitz, na Polônia. Para ele, as fotos são recursos utilizados pelos visitantes para compreender o lugar e sua história, como representações em que o passado é concebido no presente. Assim sendo, as imagens são apreendidas como tentativas de traduzir visualmente jeitos de experienciar, no agora, acontecimentos (ou o significado de acontecimentos) pretéritos. Em sua investigação, Hilmar percebe ainda que, nesse anseio interpretativo, os indivíduos se valem de certos padrões visuais, conformados por conhecimentos e sentimentos prévios e/ou evocados na experimentação mesma do espaço. Trata-se, assim, de configurações da lembrança ${ }^{4}$. O modo como tais configurações aparecem nas imagens do museu é o fio condutor da análise que se propõe.

Conceitualmente, a análise se assenta também nas noções de atualidade de Benjamin (1994), para quem o agora pode funcionar como ponto no qual passado e futuro se encontram, e de uma cristalização possível dessa atualidade como defendida por Lissovsky (2014), que, em uma leitura benjaminiana, toma a imagem fotográfica não como rastro do que 'foi', mas como resultado de um adensamento de temporalidades que comporta, de uma só vez, o passado e o futuro. É a partir dessas ideias que se pode afirmar como as imagens feitas no Memorial da Resistência trazem temporalidades que,

\footnotetext{
3 No ar desde 18 de maio de 2016, o perfil @memorialdaresistenciasp, administrado pela assessoria do museu, publica fotos que em muitos aspectos se assemelham às imagens feitas pelos visitantes, além de fazer reposts deles, isto é, republicar fotografias de visitantes que originalmente apareciam em seus perfis. Outros tipos de publicação comuns no perfil oficial do Memorial são imagens de arquivos que documentam acontecimentos históricos ligados à ditadura e de fotografias de ações educativas e culturais empreendidas pelo museu, em ambos os casos, com textos explicativos e/ou de chamada para iniciativas institucionais.

${ }^{4}$ No original, o termo utilizado por Hilmar é storyboards of remembrance, que poderia ser literalmente traduzido como 'roteiros gráficos da lembrança'. Aqui, opta-se por utilizar 'configurações da lembrança' para destituir a expressão de um caráter narrativo, destacado pelo autor em seu exame mas não tão fortemente observado nas fotografias do museu. Além disso, a escolha do termo 'configurações' se justifica pelo duplo sentido que evoca, que valoriza as formas visuais da imagem e o processo mesmo que as conforma - efeito ou ato de configurar.
} 
imobilizadas e organizadas enquanto expressões visuais, se articulam de formas variadas, como meios de ver, sentir e pensar o passado, o presente e o futuro.

\section{Do território das celas, imaginação, evidências e simbolismos}

O prédio no qual o Memorial da Resistência de São Paulo está instalado hoje é parte da Estação Pinacoteca, no Largo General Osório, na capital paulista, e foi, entre 1940 e 1983, sede estadual do DEOPS, órgão-símbolo do controle e da repressão institucionalizada no Brasil. Durante a ditadura civil-militar, diversos presos políticos foram detidos, torturados e/ou assassinados ali. Mas, como afirmam as especialistas à frente do processo que transformou o espaço em museu e lugar de memória, ao longo dos anos o local passou por uma higienização. Antes da inauguração do Memorial, elas acreditavam que os visitantes não conseguiam ter "consciência do real significado daquele lugar [...] O cenário de sede do antigo DEOPS/SP foi, em grande parte, esvaziado de indícios que remetessem ao nosso passado político" (BRUNO; CARNEIRO; AIDAR, 2009, p. 41-42).

Por causa disso, o estabelecimento do museu implicou uma remodelação que buscou recuperar elementos capazes de evocar novamente os sentidos do antigo conjunto prisional (BRUNO; CARNEIRO; AIDAR, 2009). Esse resgate faz-se mais evidente no terceiro dos quatro eixos nos quais está dividida a exposição de longa duração, intitulado A construção da memória: o cotidiano nas celas do DEOPS/SP - também denominado de 'território das celas's. Nele, têm-se quatro celas remanescentes, dois corredores de acesso e o estreito pátio que servia para o banho de sol dos militantes encarcerados, todos recondicionados como espaços para relembrar as vivências do cárcere. Assim o Memorial introduz esse eixo:

A primeira cela apresenta os trabalhos do processo de implantação do Memorial da Resistência. A segunda cela presta homenagem aos milhares de presos, desaparecidos e mortos em decorrência de ações do DEOPS/SP. Na terceira é apresentada uma reconstituição, segundo lembranças de ex-presos políticos. Finalmente, a quarta cela oferece uma leitura da solidariedade entre os que estiveram encarcerados neste local,

\footnotetext{
${ }^{5}$ Os outros eixos são: $O$ edifício e suas memórias; Controle, repressão e resistência: o tempo político e a memória; Da carceragem ao centro de referência.
} 
cujas ações de resistência colaboraram para sua sobrevivência diária. (ARAUJO; BRUNO, 2009, p. 81)

Nesse território concentra-se a maioria das fotografias feitas e compartilhadas pelos visitantes, também em maior número nas imagens coletadas nessa pesquisa (figuras 1 a 14). A partir dessa verificação, uma primeira indicação para o entendimento dessas fotos se delineia: por meio delas, as pessoas parecem tentar tocar o passado, resgatando - tal qual foi feito na criação do Memorial - uma suposta essência do que se processou nesses espaços e que então pode ser reapresentada nas imagens. Não se trata, é necessário dizer, de uma compreensão ingênua, como se os sujeitos tomassem por certo a possibilidade de reaver completamente outros tempos ao adentrar no local ou a ali fotografar. O que se destaca é o fato de essas fotografias buscarem explorar indícios do passado.

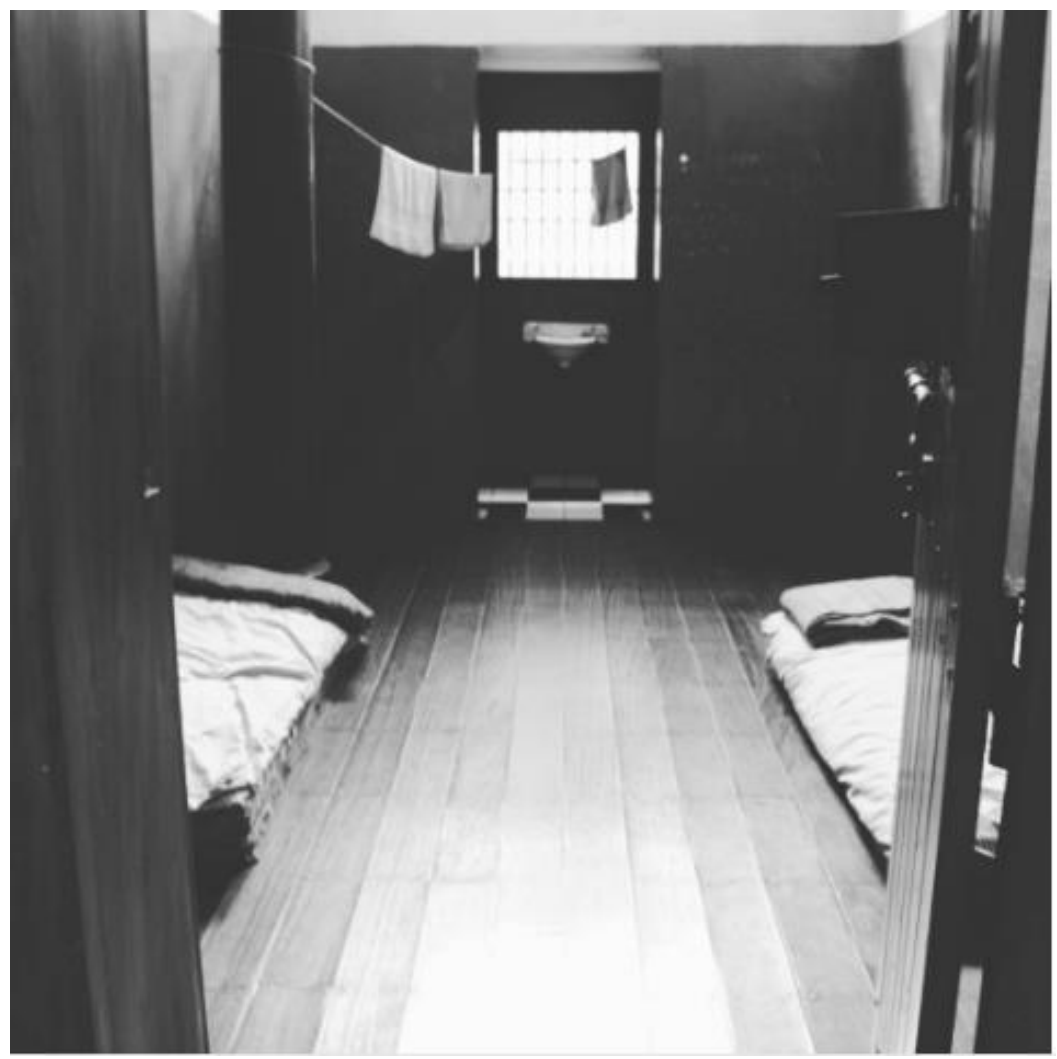

Figura 1. Foto postada no perfil @m.monteiro_tg, em 20 de novembro de 2016. 


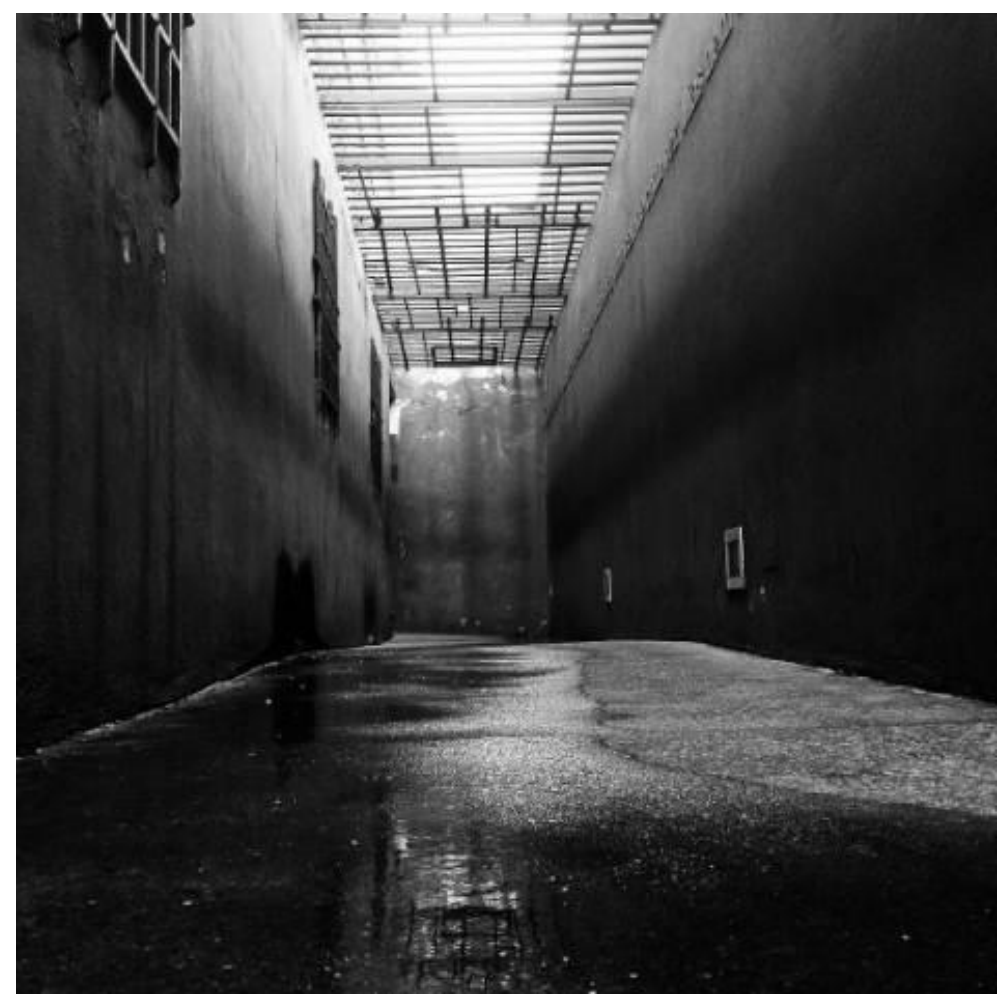

Figura 2. Foto postada no perfil @dedehyoo, em 21 de setembro de 2015.

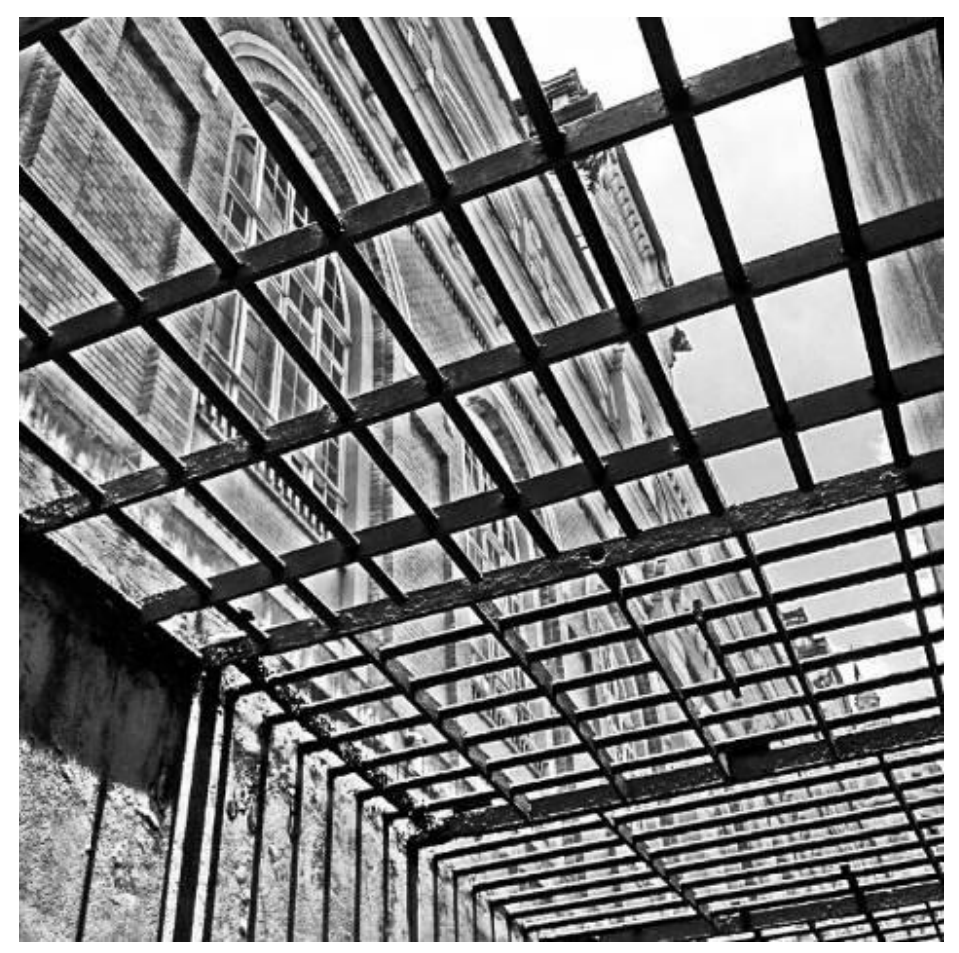

Figura 3. Foto postada no perfil @thalyatuany, em 15 de novembro de 2013. 
Ao observar com mais atenção essas imagens, algumas semelhanças começam a se destacar. Uma constante facilmente percebida é a exploração de uma maior profundidade de campo, já que todas as fotografias têm pouca ou nenhuma zona desfocada. Isso pode ser notado de forma mais marcada nas imagens que trazem planos mais abertos e que valorizam os espaços vazios, como naquelas publicadas nos perfis @m.monteiro_tg, @dedehyoo e @thalyatuany (figuras 1, 2 e 3). Essas estratégias são entendidas como uma forma de enfatizar os lugares como significantes em si mesmos, dado aquilo que se fotografa nesses casos: a reconstituição de uma cela e o antigo pátio para o banho de sol.

A escolha do filtro de conversão para o preto e branco, comum aos três visitantes que publicaram essas fotografias, parece apontar os termos dessa significação, de remissão ao passado. Assim, a estética do preto e branco pode ser apreendida como recurso de diferenciação da percepção da atualidade, que se faz 'em cores' (e, nesse sentido, as imagens funcionam como reforço para a imaginação de um outro tempo). Ademais, ela pode ser entendida como uma tentativa de associação a determinadas tradições fotográficas, como as do fotojornalismo e do fotodocumentário, nas quais a monocromia foi por muito tempo creditada como linguagem mais adequada, por seu suposto realismo (portanto, as imagens intentariam se valer de um ideal de evidência erigido nesses contextos), ou mesmo por seu efeito dramático (de ordem valorativa, na medida em que, entre imaginação e evidência, cria uma atmosfera entendida como apropriada para dar conta de uma temática funesta).

Por tudo isso, essas três imagens se aproximam de dois tipos de configuração da lembrança traçados por Hilmar (2016): imaginação da prisão (ou seja, fotos em que se fantasia o espaço e os acontecimentos históricos nele ocorridos, distanciando-se do memorial que alude à memória deles, hoje constituído) e evidência da história (isto é, imagens que focam em traços do passado, fazendo-os funcionar como testemunhos do que passou). Há ainda uma terceira configuração da qual essas fotografias se avizinham, a dos simbolismos universais, de imagens que recorrem a convenções de ordem social, 
filosófica ou religiosa para exprimir um sentido sobre o local e os fatos que ali tomaram forma, acenando a "algo maior [...], [a um] fenômeno que transcende nossa experiência diária" (HILMAR, 2016, p. 465, tradução livre ${ }^{6}$ ). A reincidência de um jogo entre dentro e fora, como referências à clausura e à liberdade, pode ser apreendido nessas três fotografias - e na postada por @bacaninha (figura 4). Em duas delas (figuras 2 e 3), essa relação entre clausura e liberdade também é constituída pelo ângulo de tomada que, de baixo para cima, enfatiza a perspectiva de um 'estar dentro' que almeja o 'estar fora'; algo mais francamente qualificado na imagem publicada por @dedehyoo (figura 2) pelo contraste tonal criado entre escuro (dentro) e claro (fora).

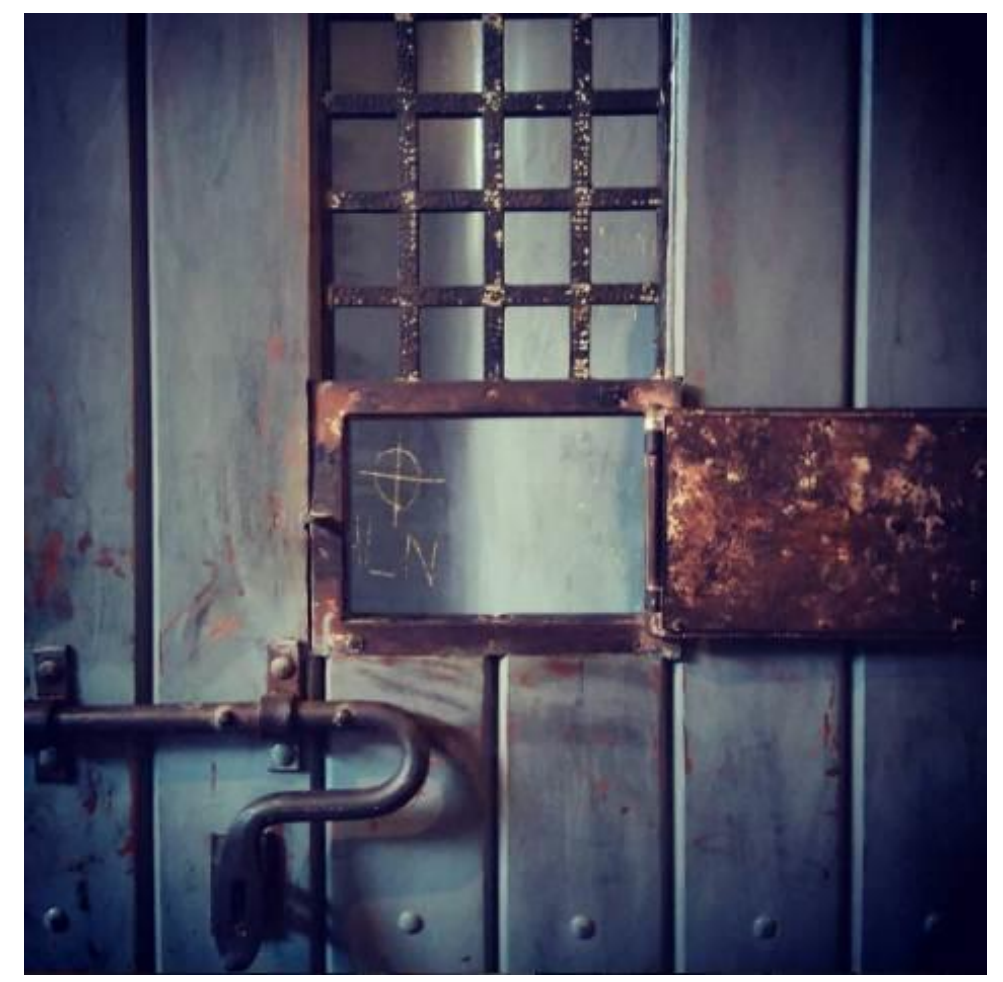

Figura 4. Foto postada no perfil @bacaninha, em 4 de setembro de 2016.

\footnotetext{
${ }^{6}$ No original: “something bigger”, [... " "phenomena which transcend our everyday experience”.
} 


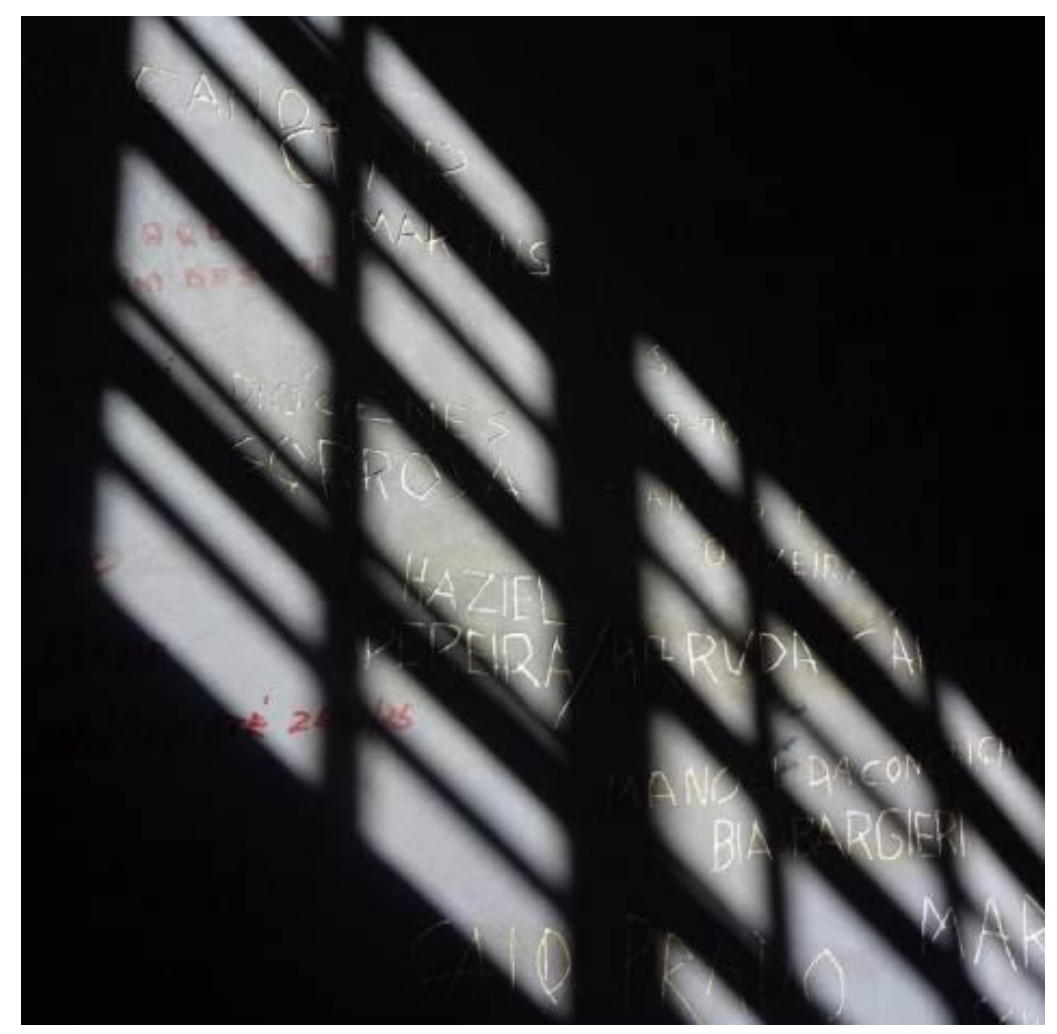

Figura 5. Foto postada no perfil @ceciliacalasans, em 20 de julho de 2014.

Esse uso simbólico do contraste tonal se repete na imagem que @ceciliacalasans posta das inscrições realizadas nas paredes da cela, por meio do manejo das luzes e das sombras (figura 5). Os escritos, entendidos como expressão do clamor dos sujeitos ali aprisionados, são tornados visíveis pela luminosidade que vem de fora, ainda que se tornem parcialmente ilegíveis pelo desenho sombreado imposto pela existência de grades na janela pela qual a luz entra. Em um processo que se estrutura entre imaginação da prisão e evidência da história, essa imagem, outra vez, edifica um sentido sobre clausura e liberdade (especificamente, sobre um resquício de liberdade possível na clausura) que se funda em uma oposição convencionada. A legenda reforça tal significação: "A luz da triste memória de um passado aprisionado”. 
O Memorial da Resistência em fotos de visitantes no Instagram: modos de ver, sentir e pensar o passado, o presente e o futuro

Ana Carolina Lima Santos

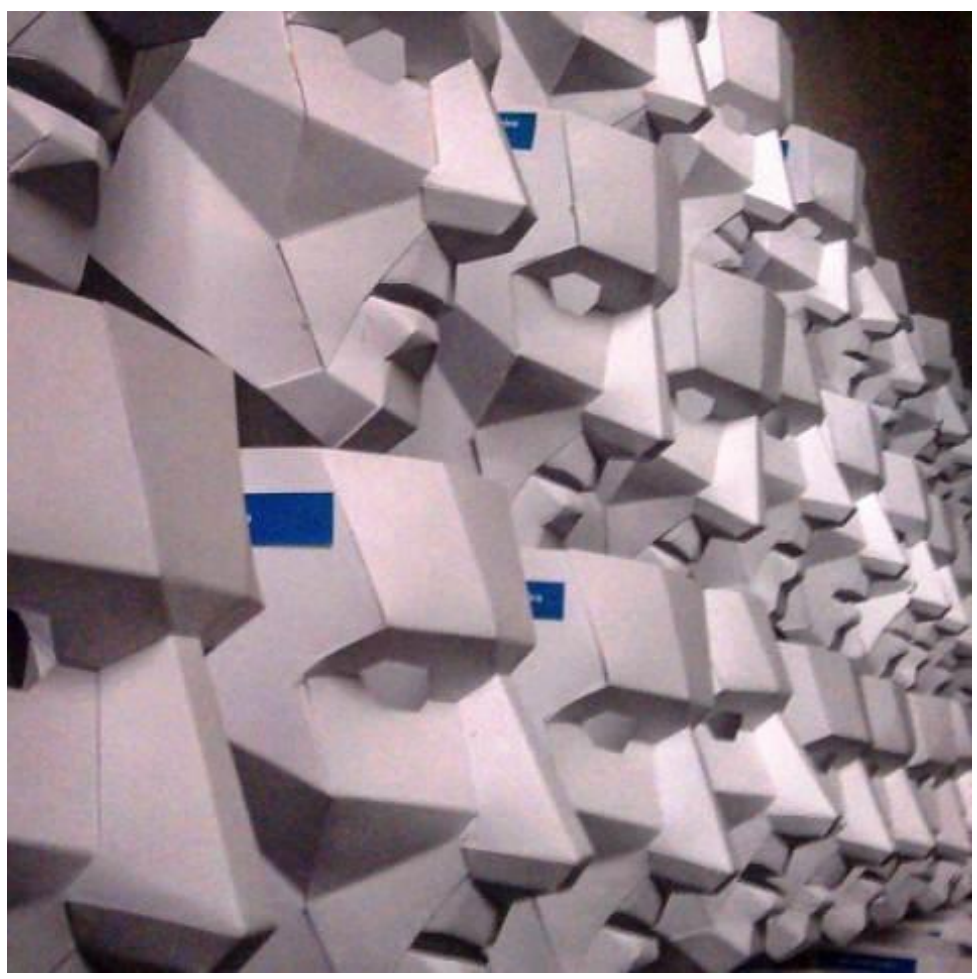

Figura 6. Foto postada no perfil @julealfotografia, em 22 de janeiro de 2017.

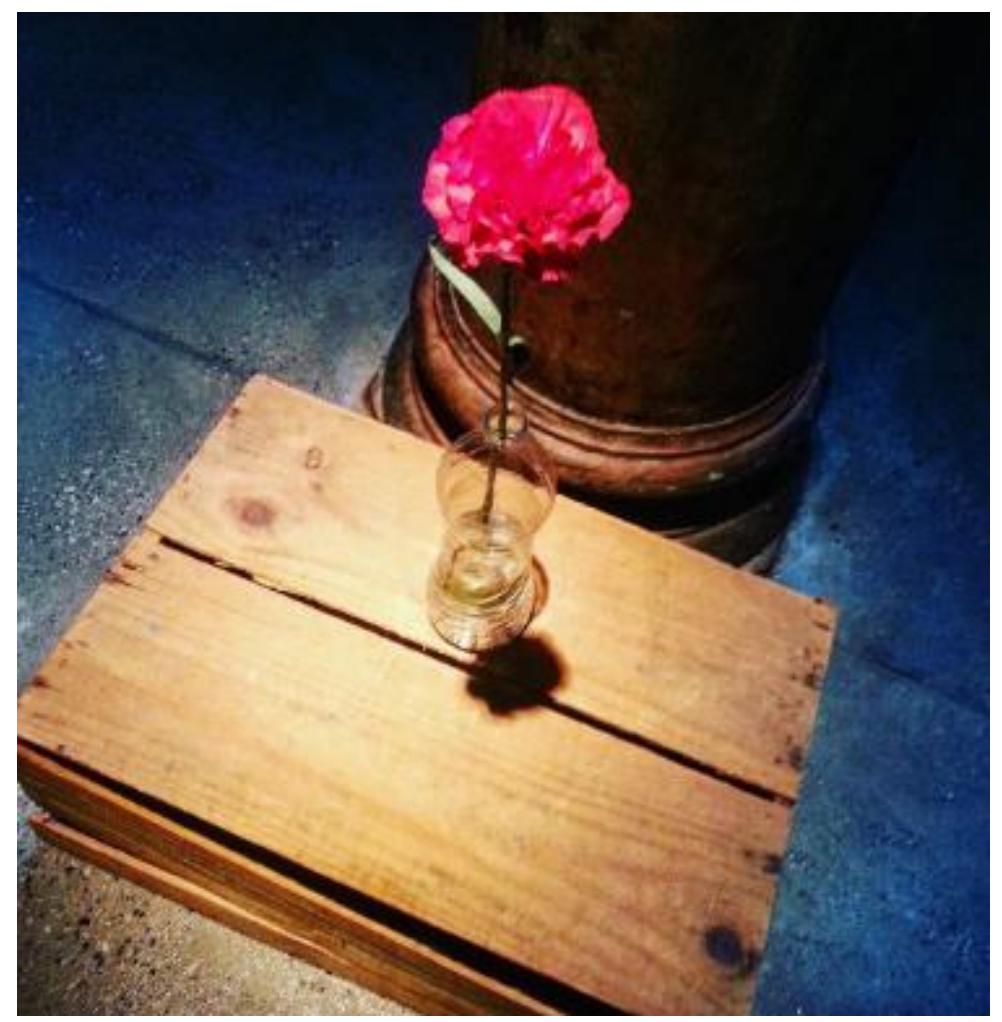

Figura 7. Foto postada no perfil @malaguetabia, em 24 de dezembro de 2016. 
Outros simbolismos comumente empreendidos se aproveitam do que já é apresentado no Memorial enquanto signo convencionado, como se verifica nas publicações feitas nos perfis @julealfotografia e @malaguetabia (figuras 6 e 7). No primeiro caso (figura 6), o objeto fotografado é parte da instalação 436, montada na segunda cela pelo artista Alexandre D’Angeli, que traz máscaras para remeter e, em alguma medida, presentificar os mortos e desaparecidos políticos brasileiros, representados na imprecisão entre identidade (da nomeação de cada indivíduo) e apagamento (de vários 'rostos' iguais, sem distinções de aparência). Na segunda fotografia (figura 7), toma-se como significante o cravo vermelho presente na quarta cela que, de acordo com o próprio Memorial, “celebra e sintetiza os singelos gestos de solidariedade que pudemos conhecer pelos relatos dos ex-presos [...], [de] cumplicidade entre aqueles que se viram privados de seus direitos básicos de sobrevivência e cidadania" (ARAUJO; BRUNO, 2009, p. 91).

Mas essa imagem em particular, ao replicar um sentido que está dado de antemão pelos responsáveis pela expografia do museu, a redimensiona pela utilização de um filtro de aumento da saturação, que intensifica as cores da fotografia. Essa estratégia de acentuação cromática é capaz de evocar, em tal imagem, uma delicadeza ambígua, ao mesmo tempo bela e angustiante. Essa ambuiguidade ajuda a conotar uma percepção sobre a solidariedade, como concebida naquelas situações. Filtros semelhantes são utilizados em outras fotos (figuras 4 e 8), a fim de pôr ênfase em aspectos sensíveis da experiência - de modos próprios, que fazem 'saltar' detalhes que dão a sensação da sujeira e da decadência do espaço e que reforçam um efeito de repulsa.

Sobre a reelaboração de algo que no Memorial funciona no âmbito do simbólico, há um último elemento a ser destacado nessas fotos. Há uma imagem da pia presente na cela que reconstitui o ambiente carcerário (figura 8) que também poderia ser encarada entre a imaginação e a evidência. Ao postar essa fotografia, o autor, @hermann.victor, escreve: “Ainda penso nessa pasta de dente 'sorriso”". Há dois modos de entender essa legenda. O primeiro aponta para um suposto deslize na reconstituição da cela, já que a marca Sorriso foi criada apenas na década de 1990, não devendo, pois, figurar na reconstituição histórica de um período anterior. O segundo baliza a ironia - proposital? de eleger uma marca que tem um nome 'feliz' para compor um cenário que busca 
despertar o contrário. Por essa interpretação, a relação verbovisual traz, na impossibilidade da evidência efetiva do passado, um pensamento sobre o significado do espaço e dos acontecimentos nele ocorridos, como construído no museu e replicado na publicação em termos visuais e verbais.

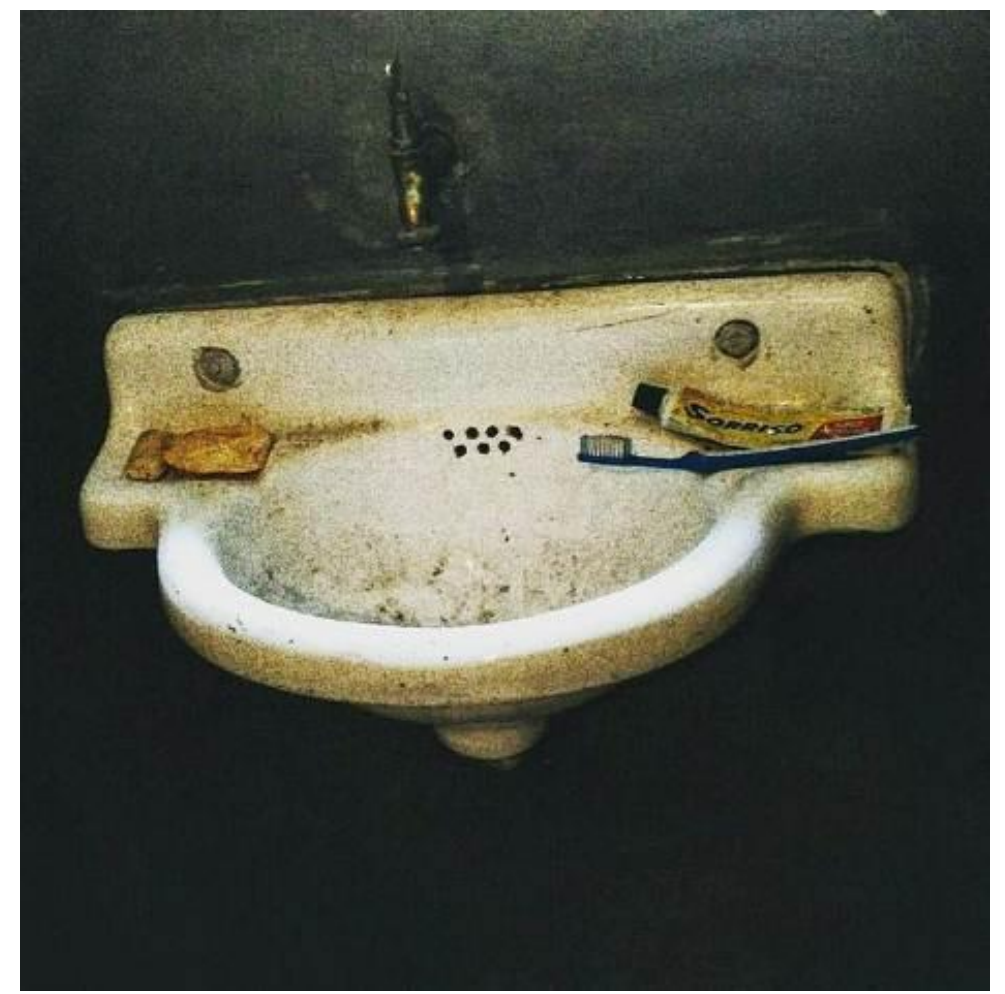

Figura 8. Foto postada no perfil @hermann.victor, em 10 de fevereiro de 2017.

\section{Dos corpos no território das celas, camadas temporais explicitadas}

Os mesmos elementos que aparecem nas imagens até agora analisadas (o espaço, objetos e inscrições da cela reconstituída e do antigo pátio para o banho de sol; as portas, janelas e grades das celas; as máscaras e a flor da expografia ali montada) servem de ponto de apoio para a construção de outro padrão encontrado entre as fotos feitas no Memorial da Resistência e compartilhadas no Instagram: os retratos. Inserindo-se na composição, frequentemente por meio de uma encenação dramática (figuras 9 a 13) e raras vezes nos moldes de um alegre selfie (figura 14), os visitantes põem seus corpos no espaço em que outrora estavam os presos políticos. Essas imagens se enquadram na configuração que Hilmar (2016) chama de camadas de tempo (em que as fotografias 
entrelaçam mais manifestadamente o presente ao passado). Se, por um lado, tais imagens parecem continuar tentando explorar vestígios do passado, por outro, elas corroboram seu caráter de presente na medida em que dão destaque à presença de personagens que se sabe alheios aos fatos pretéritos. Os indícios do passado se abrem, assim, a um jogo de cena.

A primeira questão que pode ser apontada sobre isso alude ao processo de identificação com os ex-presos políticos. O exemplo mais forte é o de um homem que se coloca em meio às mascaras da já comentada instalação 436 (figura 9). Ao posicionar-se em frente ao espaço que deveria ser ocupado por uma delas, o sujeito 'assume' o lugar daquela máscara e, por tabela, de um desaparecido.

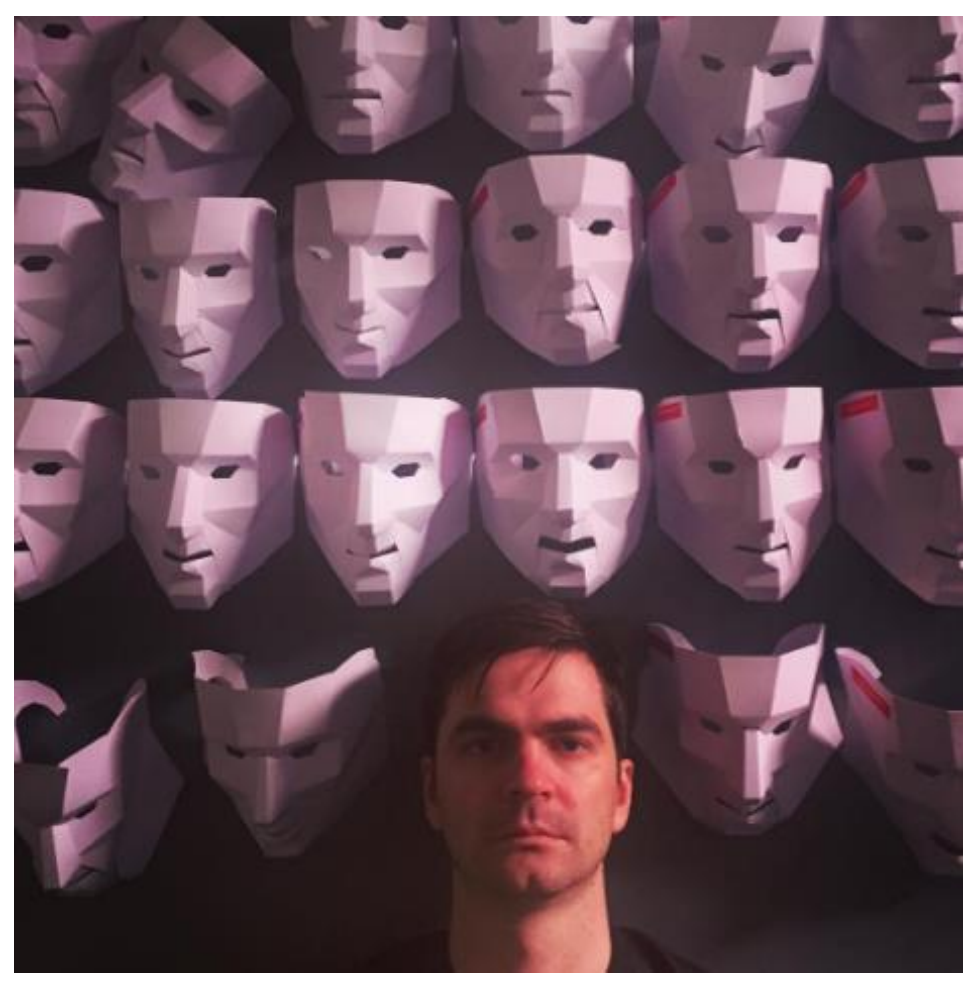

Figura 9. Foto postada no perfil @leonardo_slo, em 12 de dezembro de 2016. 


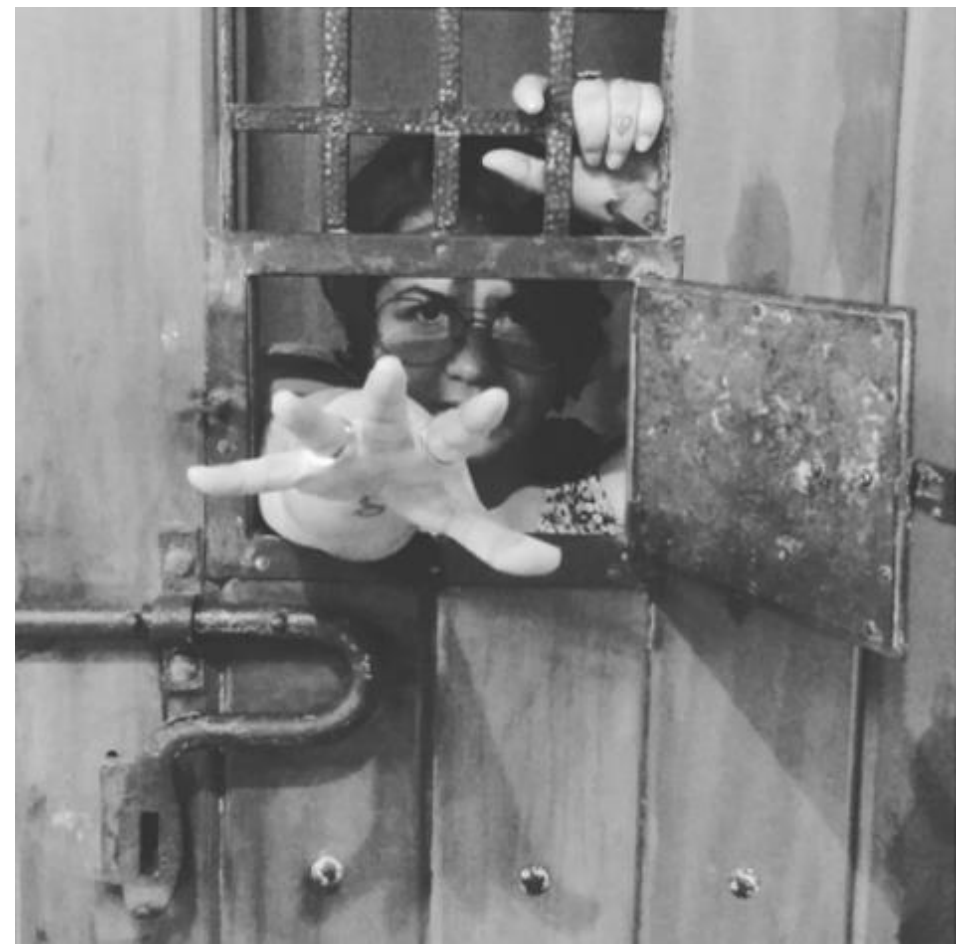

Figura 10. Foto postada no perfil @mariah_alcantara, em 18 de dezembro de 2016.

Na imagem de uma mulher que se põe atrás da porta de uma cela e estende uma das mãos por entre o postigo aberto (figura 10), igualmente, há uma tentativa de se colocar na pele de quem esteve preso no local - e fingir uma resistência ou um apelo, evocando o que acredita que de fato tenham feito os antigos prisioneiros do regime militar. Nesses casos, a configuração definida como camadas de tempo se associa com aquela da imaginação, no intuito de fantasiar, por meio da simulação, como teria sido estar naquele lugar e sofrer as violações a que foram submetidas as pessoas que ali foram detidas.

Nas postagens dessas fotos, os indivíduos evidenciam argumentos que ratificam essa ideia. A mulher, @mariah_alcantara, afirma que é “impossível saber tudo o que aconteceu atrás dessas portas. Impossível não sentir um arrepio na espinha quando você está dentro das celas que elas trancam. E eu só fiz uma visita...”. Essas palavras remetem ao que ela sente, enquanto encena o passado, ao imaginar-se como vítima dos acontecimentos passados ('um arrepio'); ainda que marque essa experiência pela via da impossibilidade ou pela incompletude de, no presente, conseguir apreender integralmente a dimensão do que se sentiu outrora ('só fiz uma visita'). Por sua vez, o 
homem, @leonardo_slo, evidencia a multiplicidade temporal para justificar o esforço imaginativo como projeção de um futuro, de um 'nunca mais' desejado: “importante não se esquecer para não se repetir", escreve.

Esse tipo de vivência, exemplificado na produção visual e na reflexão verbal dessas duas publicações, se coliga diretamente à proposta do Memorial enquanto museu e lugar de memória. Ao descrever sua percepção sobre o local, o historiador e museólogo VarineBohan (2009, p. 215) propõe pensar o espaço a partir da alternância entre a informação e a emoção. Porém, para ele, “a emoção (no meu caso) prevalece sobre a análise dos documentos apresentados e sobre a simples compreensão dos mecanismos psicológicos, administrativos e jurídicos". Esse entendimento é percebido por Andermann e Simine (2012) como característico de uma nova tendência dos museus, que se deslocam de um discurso historiográfico explicativo, imposto de cima para baixo, para dar vez a práticas horizontalizadas que envolvem os visitantes na própria constituição dos sentidos pretendidos. Para tanto, é habitual que esses museus objetivem

[...] facilitar o aprendizado experienciado, convocar respostas emocionais dos visitantes e induzir empatia e identificação com as pessoas do passado [...] para que, ao 'reviver' suas experiências, os sujeitos desenvolvam formas mais pessoais e imediatas de engajamento afetivo e de investimento imaginativo. (ANDERMANN; SIMINE, 2012, p. 78 , tradução livre7)

O engajamento, no caso dessas duas imagens analisadas, se dá por meio de uma encenação na qual o visitante se põe como personagem ativo, imaginando e simulando experiências pretéritas. Essa atitude, supõe-se, é desejada e encorajada pelo Memorial, pela ênfase que dá a essas noções de experiência, empatia e identificação, como destacadas por Andermann e Simini. O modo como a expografia é arquitetada no território das celas parece, de fato, convidar os visitantes a experimentarem, a partir do presente, resquícios do passado. O vazio, antes constatado, é estratégico: esvaziado da presença humana, o espaço só pode ser preenchido pelos sujeitos que por ali passam.

\footnotetext{
7 No original: "to facilitate experiential learning, to invite emotional responses from visitors and to make them empathize and identify with people from the past [...], as if 'reliving' their experience, in order to thus develop more personal and immediate forms of affective engagement and imaginative investment".
} 
Temporariamente 'presos' naquele espaço, os visitantes fazem as vezes do personagem cuja presença é referenciada, mas não efetivada - o preso político de outro tempo.

A presença e o envolvimento dos sujeitos no território das celas também é marcada pela criação de cenas que, sem remeter a acontecimentos passados, os conotam na seriedade (figura 11), na introspecção (figura 12) e na atenção (figura 13), como fazem as pessoas presentes nas fotografias postadas nos perfis@maelo70, @vinni.lobo e @fabianamaranhao. Assim como as duas imagens anteriores, essas fotos trazem um caráter performativo mais acentuado, ou seja, são abalizadas por uma atuação que se dirige ao olhar de outrem.

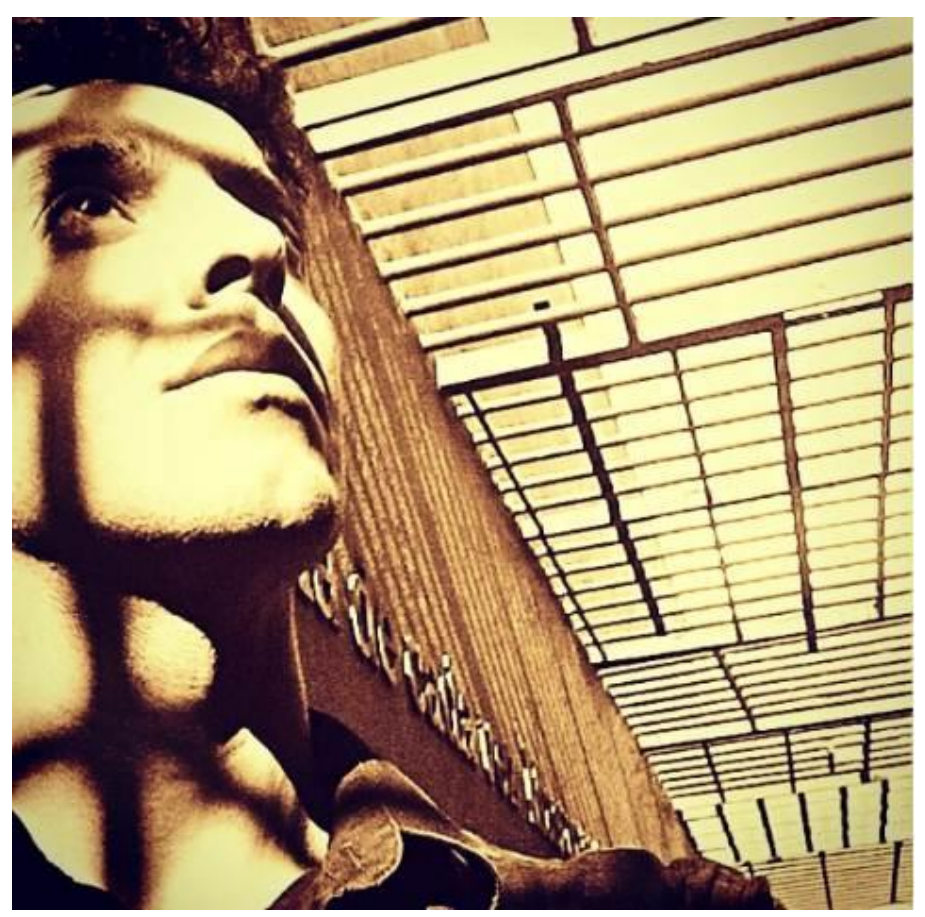

Figura 11. Foto postada no perfil @maelo70, em 20 de outubro de 2015. 
O Memorial da Resistência em fotos de visitantes no Instagram: modos de ver, sentir e pensar o passado, o presente e o futuro

Ana Carolina Lima Santos

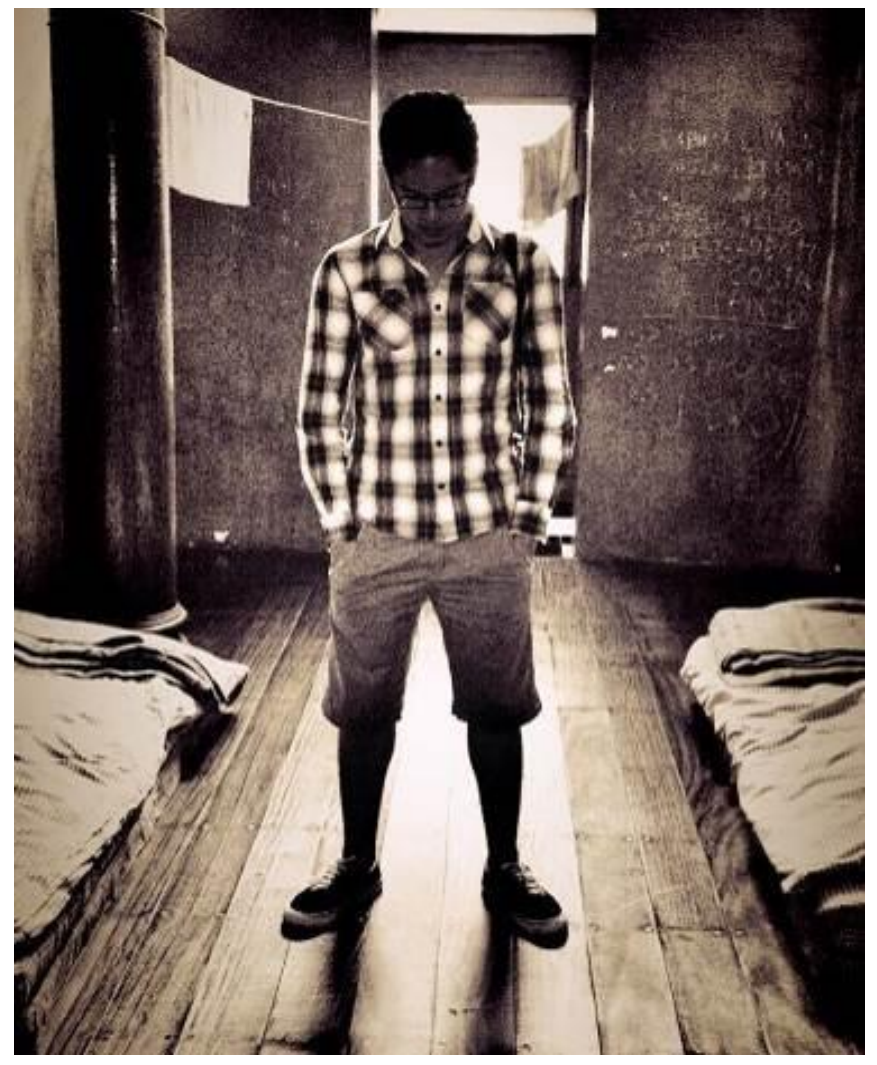

Figura 12. Foto postada no perfil @vinni.lobo, em 10 de agosto de 2016.

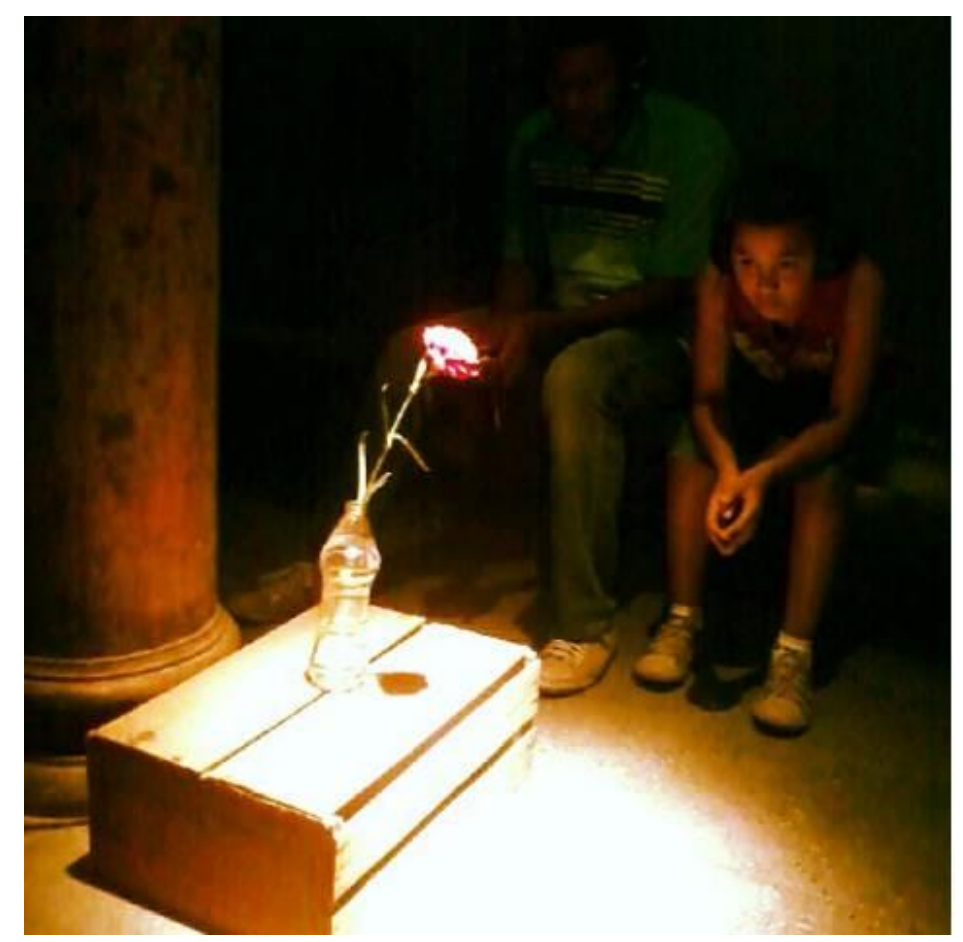

Figura 13. Foto postada no perfil @fabianamaranhao, em 27 de maio de 2012. 
Nesse ponto, é fundamental reconhecer que o caráter público dessas imagens ganha peso: além de servir aos propósitos interpretativos, nos moldes defendidos por Hilmar $(2016)^{8}$, as fotografias são construídas para exercer a função de interação entre sujeitos que perpassa o uso do Instagram, estando, portanto, ancorada em aspirações de visibilidade e validação (SILVERMAN, 2015). Dito de outro modo, a produção da imagem não deve ser pensada apenas como guiada pela pretensão dos visitantes de compreender o lugar e sua história, mas ainda por seu caráter relacional, de uma fotografia que se assinala pela vontade de interlocução, criada por um sujeito que busca exibir-se e possivelmente agradar a um público que se tem no horizonte.

A interação, a visibilidade e a validação que quase sempre se ambicionam nas redes sociais implicam, por conseguinte, na performance que se adota em cada caso. É isso, acredita-se, que explica porque algumas pessoas, mesmo podendo saber o significado daquele espaço e do que ali aconteceu, decidem posar sorridentemente para uma selfie, como fazem as mulheres da foto publicada por @vitoriabertuzzi (figura 14): para elas, mais importa valer-se da ideia de felicidade, um atributo desejável no Instagram, e rotular a ida ao museu como um passeio prazeroso feito com as amigas, uma atividade valorizada nas redes ${ }^{9}$. A legenda parece seguir essa ideia, ao descrever um

\footnotetext{
${ }^{8}$ É preciso sinalizar, em relação a esse aspecto, a diferença metodológica entre este trabalho e o de Hilmar. Como explicado anteriormente, as imagens aqui analisadas foram coletadas no Instagram e, como a maior parte das fotografias que estão ali, foram feitas para serem compartilhadas na rede ou, ao menos, foram compartilhadas de modo deliberado pelos fotógrafos e/ou fotografados. Hilmar, distintamente, recolhe as imagens por ele examinadas em um estudo etnográfico in loco no qual as pessoas eram convocadas a mostrar imagens que fizeram durante a visita a Auschwitz e que não necessariamente foram produzidas para serem publicizadas.

9 Esse exemplo evidencia algumas tensões que o fazer fotográfico pode trazer no contexto de um museu e lugar de memória que trata de eventos traumáticos. Outro caso que pode ser apontado, destacado pela notoriedade que ganhou recentemente, é a proliferação de fotos dos mais variados tipos no Memorial aos Judeus Mortos da Europa, em Berlim. No início de 2017, um projeto intitulado Yolocaust, realizado pelo artista Shahak Shapira, trouxe à tona as polêmicas envolvendo certa maneira de apropriação imagética daquele espaço, entendida como desrespeitosa. Nele, Shapira combinou doze retratos retirados de redes sociais, de pessoas sorrindo, brincando, pulando e fazendo poses descontraídas no memorial, com fotos de campos de extermínio em que é possível ver pilhas de corpos ou indivíduos esqueléticos à beira da morte. A montagem é feita de tal maneira que faz parecer que os sujeitos tripudiam ou ao menos se mostram indiferentes às vidas dizimadas no passado, que ali hoje se rememora. As tensões sobre o comportamento adequado em lugares dessa natureza podem ser extrapoladas para além do âmbito do fotográfico. Em 2016, no auge da febre do Pokémon Go (jogo baseado em geolocalização e realidade aumentada, no qual os usuários precisam capturar criaturas virtuais em ambientes reais), o memorial sediado no antigo campo de extermínio de Auschwitz teve que proibir o uso do jogo em seus espaços. "O antigo campo nazista não é somente um museu, ele é, antes de tudo, um
} 
“banho de sol com as meninas da \#FundaçãoGoldeLetra no \#DEOPS!!!!!". A influência do caráter público dessas fotografias, mais evidente nesse caso pelo clichê que encarna, atravessa as encenações dramáticas (figuras 9 a 13), arquitetando-se por outra via, de quem quer se autoconstruir como indivíduo politizado e engajado, sabedor e comprometido com uma consciência histórica.

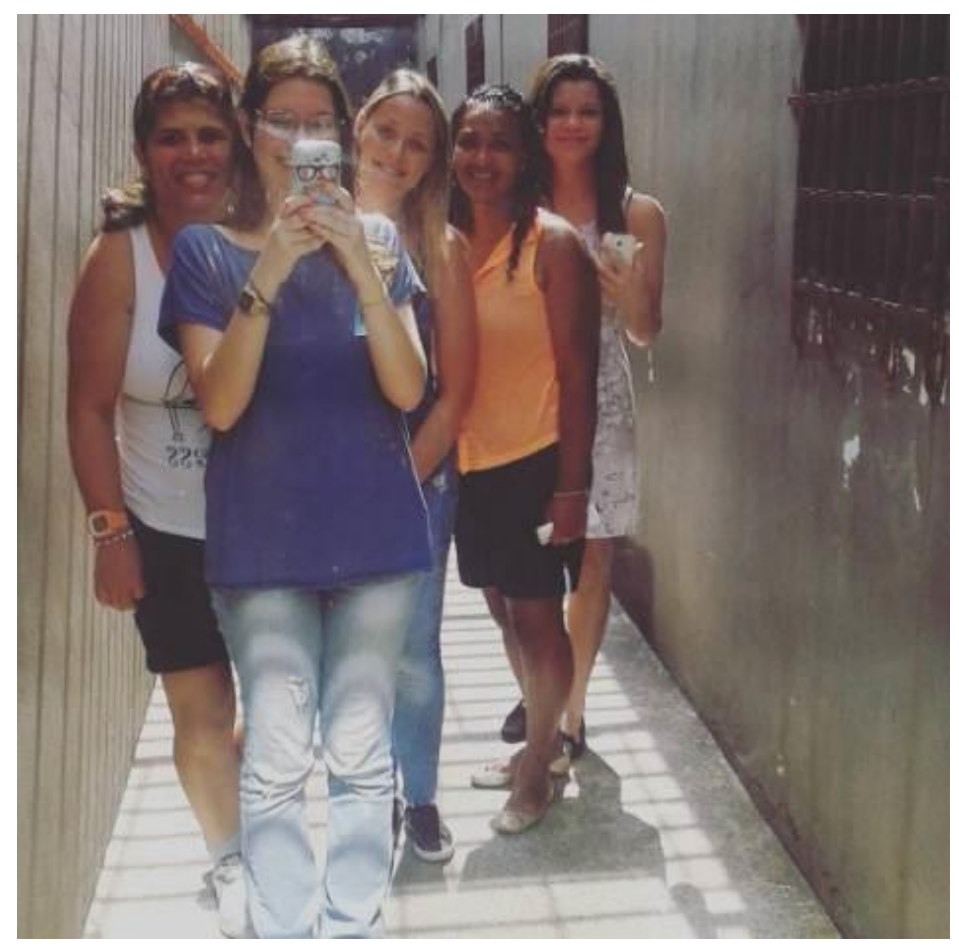

Figura 14. Foto postada no perfil @vitoriabertuzzi, em 19 de novembro de 2015.

Seguindo essa lógica, pode-se conceber que mesmo as fotografias em que não aparecem personagens (figuras 1 a 8) estão condicionadas por seu caráter público. Ainda que não torne visível uma performance corporal, essas imagens também são frutos daquilo que Jurgenson (2012) nomeia de olho 'facebookiano' (no original: Facebook eye) ou, como pode se ampliar para esses casos, resultado do olho 'instangramzeiro'. Esse olho é por ele definido pela busca incessante "por momentos em que o borrão efêmero da experiência vivida poderia ser melhor traduzido em uma postagem de Facebook; uma

lugar de memória, um lugar onde as pessoas comparecem também para refletir e orar, por isso que é inconcebível que seja tratado como um espaço para jogos ou diversão [...] Trata-se de uma atividade totalmente inadequada em um lugar onde centenas de milhares de pessoas sofreram e perderam a vida", justificou o porta-voz do memorial, Bartosz Bartyzel. Informações disponíveis em: <http://yolocaust.de e http://efe.com/efe/brasil/tecnologia/museu-de-auschwitz-proibe-visitantes-jogar-pokemon-go/50002452985652>. Acesso em: 15 abr. 2017. 
que irá gerar mais comentários e curtidas" (JURGENSON, 2012, s/p, tradução livre ${ }^{10}$ ). Trata-se, também, de um caráter performativo. Essa constatação, contudo, não parece diminuir o valor de nenhuma dessas imagens enquanto agentes de um anseio interpretativo, somente as reconfiguram com demandas de interação, visibilidade e validação; estas tendo que se compatibilizar com aquele e vice-versa. Assim, entende-se que, juntas, essas duas faces das mesmas fotografias se coligam e se fortalecem mutuamente. Afinal, é porque são capazes de traduzir em imagens as experiências dos donos de cada perfil do Instagram, dando forma por meio de interpretações que envolvem suas personalidades, seus pensamentos e seus sentimentos, que as fotos estão aptas a serem publicadas nesse espaço de autoconstrução, dando visibilidade e buscando validação às subjetividades.

\section{Fora do território das celas, outros simbolismos e outras camadas de tempo}

Embora não sejam tão numerosas como as fotografias feitas no território das celas, há imagens realizadas em outros eixos do Memorial da Resistência de São Paulo, em especial no eixo Controle, repressão, resistência: o tempo político e a memória (figuras 15 e 16). Nessas, a principal repetição constatada é a centralidade dada a elementos verbais presentes no lugar (figura 15 e 16). A primeira foto que pode ser destacada é aquela publicada no perfil @darlan.lopes (figura 15). Ela traz a frase "enquanto lembramos tudo é possível”, citação tomada de empréstimo de Elie Wiesel, escritor judeu sobrevivente de um campo de extermínio nazista e utilizada no museu como mote para resumir o espírito de resistência do seu projeto museológico, que confia no potencial de rememoração e de consciência sobre o passado como motivador de novas perspectivas e aspirações. No Memorial, o dito encontra-se plotado sobre uma faixa laranja e colada em uma porta de vidro translúcido.

\footnotetext{
${ }^{10}$ No original: "for moments where the ephemeral blur of lived experience might best be translated into a Facebook post; one that will draw the most comments and likes".
} 


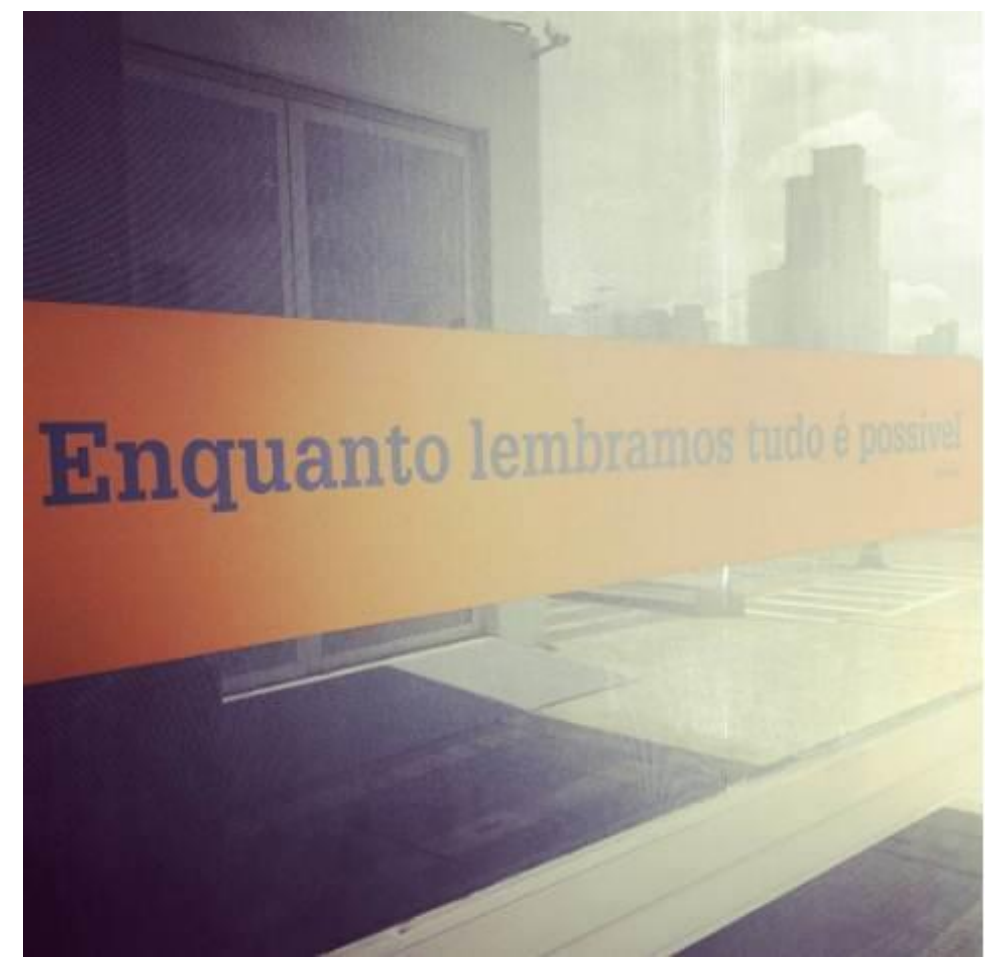

Figura 15. Foto postada no perfil @darlan.lopes, em 8 de dezembro de 2016.

Mas o modo como essa proposição verbal é dada a ver na imagem adiciona significados a ela. Na fotografia, a superfície vítrea se destaca por aquilo que permite enxergar lá fora, a cidade. A urbe, que pode ser tomada em referência aos homens e à sociedade, parece assinalar de quem é a responsabilidade de levar adiante as novas perspectivas e aspirações apontadas ali dentro. Outro dado da imagem, contudo, abaliza um sentido distinto: pela luminosidade, mais forte no lado direito da fotografia, o final do enunciado esmaece - talvez em alusão a uma memória que insiste em se apagar, apesar dos esforços da instituição; talvez como sinal de descrença de que 'tudo' seja mesmo 'possível'. Por essas interpretações, a foto pode ser pensada entre as configurações das camadas temporais (por evidenciar a ideia de lembrança da ditadura, que se faz possível apenas quando há um presente antecedido pelo reconhecimento de um passado) e dos simbolismos universais (mais uma vez, pela oposição dentro-fora e também pela contraposição entre vividez e apagamento).

Em tal aspecto, a imagem ajuda a configurar o espaço como um templo da memória. A verbalidade tanto quanto a visualidade servem, assim, para explicitar o que ali se guarda de mais valioso, a saber, as próprias lembranças. Por essa via, a fotografia se 
coliga a outras já analisadas, em que a rememoração é tipificada (figuras 11 a 13) - com a diferença de que, se, naqueles exemplos, essa tipificação se dava pela encenação; nessa, ela se dá pelas relações verbovisuais estabelecidas.

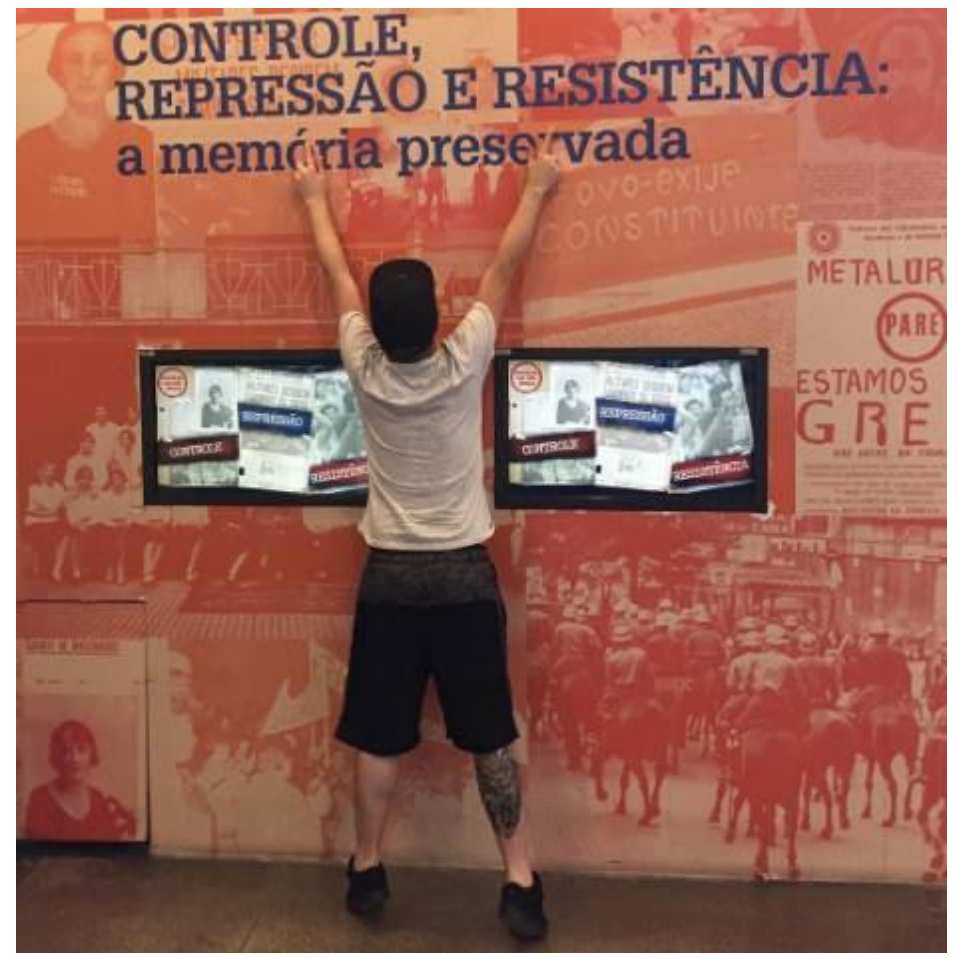

Figura 16. Foto postada no perfil @danilopasini, em 9 de março de 2017.

Algo semelhante pode ser constatado na publicação do perfil @danilopasini (figura 16). A verbalidade escolhida é o título do eixo que se enxerga acima de um material audiovisual com informações sobre acontecimentos ligados à ditadura civilmilitar. Na imagem, a questão da exibição dos corpos dos sujeitos, abordada antes, reaparece não exatamente como uma encenação dramática, mas a partir de um indivíduo que se põe em cena para apontar duas palavras ('repressão' e 'resistência'), como se quisesse sublinhá-las. A presença do homem, nesse caso, também indica a possibilidade da rememoração: é porque ele está ali, performando a memória, que a repressão e a resistência podem ser relembradas. 'Estou aqui para recordar' parece indicar essa e as demais pessoas que se colocam em cena (figuras 9 a 13). 
Para além da verbalidade, outro destaque entre as imagens tiradas fora do território das celas é a recorrência à figura do arquivo presente no quarto eixo, Da carceragem ao centro de referência. Em algumas fotos, ele aparece como elemento de ambientação de uma encenação, como acontece na publicação do perfil @moniquemerin (figura 17). Essa dramatização, além de evocar outros elementos já tematizados, pode ser encarada como uma exploração do arquivo como lugar do passado e do presente.

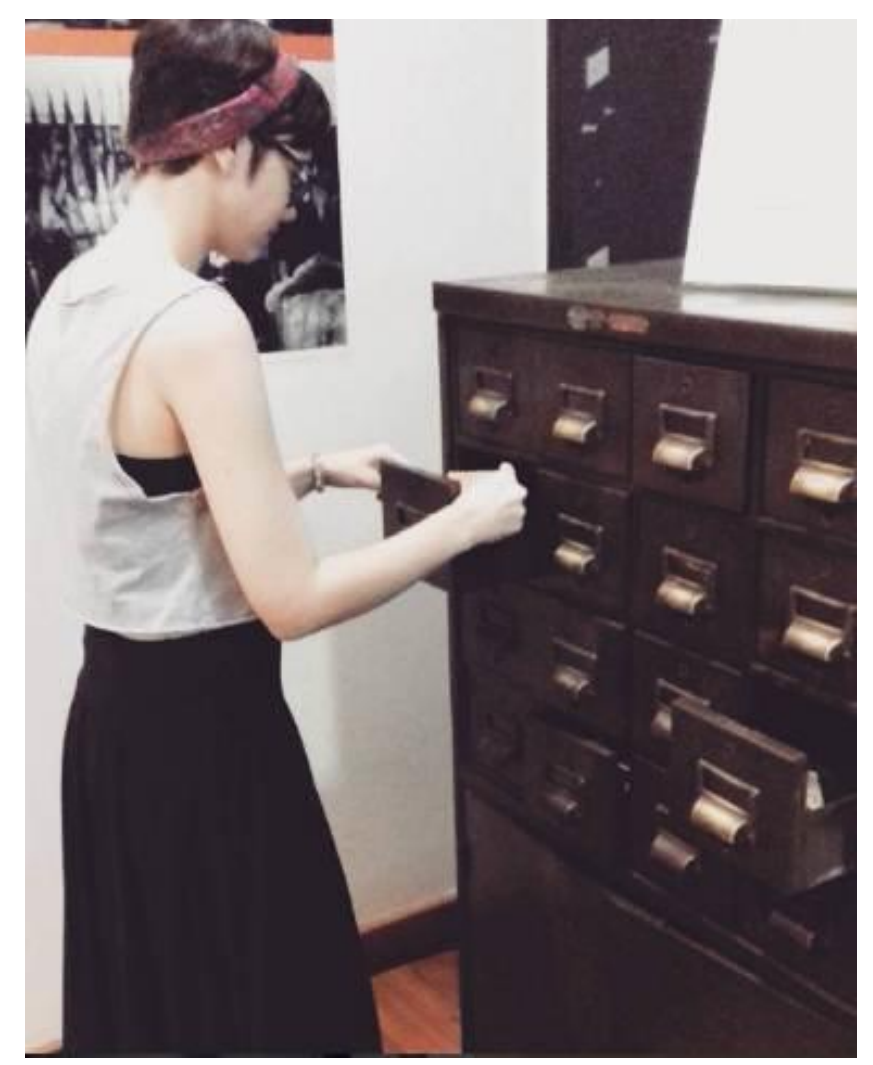

Figura 17. Foto postada no perfil @moniquemerin, em 21 de dezembro de 2016.

Se, por uma via, o arquivo é detentor e preservador de informações sobre o passado, nesse caso, acerca de acontecimentos sobre a ditadura (o que também se explicita em duas das hashtags que acompanham a postagem: \#histórianacional e \#história); por outro, na possibilidade que ele descortina, representada pela ação da mulher que abre uma de suas gavetas e folheia as fichas que ali se localizam, o presente se desenha de forma ativa, como possibilidade de (re)descoberta e (re)construção. Como lembram Falci e Alencar (2015, p. 160), o arquivo, assim como a memória, comporta essas duas temporalidades "em constante estado de devir", sempre passíveis de implicar-se 
mutuamente. Sobre isso, eles dizem ainda que é preciso "reconhecer que a questão primordial do arquivo não é o passado, mas sim o futuro, posto que o arquivo nada mais é do que uma promessa, uma responsabilidade para o futuro que permite recuperar a memória" (FALCl; ALENCAR, 2015, p. 154). Nesse aspecto, a imagem funciona como uma metáfora para a própria experiência de estar naquele museu e lugar de memória, evidenciando as camadas de tempo que ela admite.

\section{Considerações finais}

A partir da última fotografia examinada (figura 17), começou-se a apontar mais explicitamente aquilo que perpassou toda a análise das imagens: as múltiplas articulações que nelas se estabelecem entre passado, presente e futuro. As correspondências entre temporalidades, que se dão sempre de forma fragmentada, quando o presente visa o passado e o futuro, dizem respeito à própria experiência do tempo histórico, como apropriação atualizadora - "apropriar-se de uma reminiscência tal como ela relampeja no momento de um perigo", assegura Benjamin (1994, p. 225). A fotografia, de acordo com certo entendimento, assume lugar privilegiado, uma vez que confere uma chance de legibilidade, ao imobilizar e cristalizar as centelhas desse relampejar (LISSOVSKY, 2014). No caso das imagens feitas nos limites do Memorial da Resistência de São Paulo, acreditase que elas elucidam, através de experiências particulares, a produção de sentido sobre o museu e o lugar de memória, sobre aquilo que a experiência dentro dele (re)configura nos modos de ver, de sentir e de pensar a questão da resistência. Reconhece-se, pois, que há nessas fotos elementos que podem aclarar algo sobre o passado e o futuro, em seu princípio construtivo, isto é, em sua capacidade de acender significados de uma e de outra época.

Esse poder se manifesta mesmo quando a fotografia se funda em uma prática que muitas vezes se classifica como banal ou desnecessária, dessa produção desenfreada de imagens que registram cada passo do cotidiano dos sujeitos. E ele desponta mesmo quando a foto circula em um lugar supostamente apaziguador ou fútil, como o Instagram. Nas redes sociais, nas quais qualquer iluminação parece ser soterrada pela abundância, essa chance singular de esclarecimento continua se fazendo possível, "nas marcas das 
conexões, entre as conexões e no movimento que formos capazes de fazer entre elas [entre as imagens]" (FALCl; ALENCAR, 2015, p. 162). É isso que, defende-se, essas fotografias solicitam do agora da reconhecibilidade.

Das imagens aqui analisadas, alguns sentidos são traçados, estendendo-se das qualificações sobre a liberdade (figuras 1 a 5 ) e a solidariedade (figura 7), passando pela valorização dos sujeitos outrora implicados (figuras 6, 9 e 10) e do peso de certos acontecimentos (figuras 8, 11, 12, 13 e 16) e chegando à necessidade de buscar responsabilizar-se por eles ou ao menos assumir a tarefa de compreendê-los e relembrálos (figuras 15 e 17). Tudo isso, tomado no empenho interpretativo que se realiza na experiência em um museu e lugar de memória e na visibilidade/validação que as fotografias assumem no contexto das redes sociais, dá volume e consistência a visões, sentimentos e pensamentos "sobre as atrocidades da repressão, mas, sobretudo, [acerca d]as inspirações para a valorização da solidariedade, dos princípios democráticos e do respeito à diferença", como se defende na proposta do Memorial (ARAUJO; BRUNO, 2009, p. 75). Mais do que isso, as imagens podem inervar as formas de ver, sentir e pensar, dirigindo-se a quem as olha para solicitar que as tensões que carregam sejam descortinadas - como este artigo se esforçou em fazer.

Uma última tensão merece ser apontada e ela não tem a ver com o que se enxerga nas fotografias ou nas vinculações possíveis entre elas, mas naquilo que ali não se avista. Se a lembrança sempre envolve esquecimentos, a visibilidade também sempre abarca invisibilidades. O grande esquecimento ou invisibilidade que se impõe nessas imagens recai sobre a figura do algoz - do militar, do carcereiro, do torturador. Essa é, também, uma ausência que se pode perceber no próprio Memorial ${ }^{11}$. Ao dar-se conta dessa falta, um significado perverso pode ser empreendido da postagem feita no perfil @moniquemerin (figura 17). Se tomada não apenas pela chave do presente, mas também pela do passado (como demarcado por outras encenações, das figuras 9 e 10), a performance da mulher adquire novo contorno. Ao invés de simular e assumir o papel de

\footnotetext{
1 Essa ausência se fundamenta no projeto museológico do espaço, que opta em lançar seu foco na perspectiva da resistência - e não da repressão. Além disso, outras questões legais e morais parecem influenciar essa ausência, até mesmo pelo estágio de desvelamento dos crimes ditatoriais quando da fundação do Memorial, que é anterior à criação da Comissão Nacional da Verdade, de maio de 2012.
} 
uma visitante que experiencia o museu e lugar de memória, ela seria uma agente de outrora a remexer os registros dos prisioneiros e alvos do regime ditatorial. Essa dimensão velada, certamente inconsciente e não pretendida pela personagem, se infiltra na fotografia pela persistência do não reconhecimento sobre tudo o que ocorreu no interior do DEOPS, em especial no que diz respeito a responsabilidades, nunca judicialmente atribuídas ou publicamente admitidas.

\section{Referências}

ANDERMANN, Jens; SIMINE, Silke Arnold-de. Memory, community and the new museum. Theory, Culture \& Society, Los Angeles, London, New Delhi and Singapore, v. 29, n 1, jan. 2012. Disponível em: http://journals.sagepub. com/doi/full/10.1177/0263276411423041. Acesso em: 30 abr. 2017.

ARAUJO, Marcelo Mattos; BRUNO, Maria Cristina Oliveira. A ocupação dos espaços e a articulação entre as linguagens expositivas: a construção dos sentidos e significados inerentes aos enfoques temáticos. In: ARAUJO, Marcelo Mattos; BRUNO, Maria Cristina Oliveira (Org.). Memorial da Resistência de São Paulo. São Paulo: Pinacoteca do Estado, 2009, p. 69-97.

ARAUJO, Marcelo Mattos; BRUNO, Maria Cristina Oliveira; NEVES, Kátia Felipini; MENEZES, Caroline Grassi Franco. Avaliação e a experiência cotidiana. In: ARAUJO, Marcelo Mattos; BRUNO, Maria Cristina Oliveira (Org.). Memorial da Resistência de São Paulo. São Paulo: Pinacoteca do Estado, 2009, p. 165-169.

BENJAMIN, Walter. Sobre o conceito da História. In: MAGIA E TÉCNICA, ARTE E POLÍTICA. São Paulo: Brasiliense, 1994, p. 222-232.

BRUNO, Maria Cristina Oliveira; ARRUDA, Beatriz Cavalcanti; FIGOLS, Francisca Aida Barboza. Plano museológico. São Paulo: Pinacoteca do Estado, 2010. Disponível em: http://memorialdaresistenciasp.org.br/memorial/Upload/file/MRSP_PLANO_MUSEOLOGI CO_COMPLETO.pdf. Acesso em: 7 jan. 2017.

BRUNO, Maria Cristina Oliveira; CARNEIRO, Maria Luiza Tucci; AIDAR, Gabriela. Projeto museológico de ocupação. In: ARAUJO, Marcelo Mattos; BRUNO, Maria Cristina Oliveira (Org.). Memorial da Resistência de São Paulo. São Paulo: Pinacoteca do Estado, 2009, p. 39-49.

FALCl, Carlos Henrique; ALENCAR, Renata. O arquivo sob tensão: abundância, descontinuidades e desejo de memória. Devires, Belo Horizonte, v. 12, n. 2, jul. 2015. 
Disponível em: http://fafich.ufmg.br/devires/in dex.php/devires/article/view/139/202. Acesso em: 19 mai. 2017.

HILMAR, Till. Storyboards of remembrance: representations of the past in visitors' photography at Auschwitz. Memory Studies, Glasgow, v. 9, n. 4, out 2016. Disponível em: http://journals.sagepub.com/doi/ abs/10.1177/1750698015605572. Acesso em: 18 jan. 2017.

JURGENSON, Nathan. The Facebook eye. The Atlantic, Washington, 13 jan. 2012. Disponível em: http://theatlantic.com/technology/archive/2012/01/the-facebookeye/251377. Acesso em: 30 abr. 2017.

LISSOVSKY, Mauricio. Pausas do destino: teoria, arte e história da fotografia. Rio de Janeiro: Mauad, 2014.

SILVERMAN, Jacob. 'Pics or it didn't happen' - the mantra of the Instagram era. The Guardian, Londres, 26 fev. 2015. Disponível em:

http://theguardian.com/news/2015/feb/26/pics-or-it-didnt-happen-mantra-instagram-erafacebook-twitter. Acesso em: 30 abr. 2017.

VARINE-BOHAN, Hugues de. Os princípios da Sociomuseologia a serviço da preservação da memória da resistência política: uma reflexão sobre as metodologias aplicadas ao projeto. In: ARAUJO, Marcelo Mattos; BRUNO, Maria Cristina Oliveira (Org.). Memorial da Resistência de São Paulo. São Paulo: Pinacoteca do Estado, 2009, p. 209-221.

Recebido em 13/04/2018 Aprovado em 26/04/2019

Universidade do Estado de Santa Catarina - UDESC

Programa de Pós-Graduação em História - PPGH

Revista Tempo e Argumento Volume 11 - Número 27 - Ano 2019 tempoeargumento@gmail.com 